Abstracta Iranica Abstracta Iranica

Revue bibliographique pour le domaine irano-aryen

Volume 32-33 | 2013

Comptes rendus des publications de 2009-2010

\title{
Ibn-'Arabi, A. Penot. Les Révélations de la Mecque. [Anthologie traduite, commentée et annotée par A. Penot]
}

Ève Feuillebois-Piérunek

\section{(2) OpenEdition}

1 Journals

Édition électronique

URL : http://journals.openedition.org/abstractairanica/40312

DOI : $10.4000 /$ abstractairanica.40312

ISSN : 1961-960X

Éditeur :

CNRS (UMR 7528 Mondes iraniens et indiens), Éditions de l'IFRI

\section{Édition imprimée}

Date de publication : 1 décembre 2013

ISSN : 0240-8910

Référence électronique

Ėve Feuillebois-Piérunek, «Ibn-'Arabi, A. Penot. Les Révélations de la Mecque. [Anthologie traduite, commentée et annotée par A. Penot] », Abstracta Iranica [En ligne], Volume 32-33 | 2013, document 372, mis en ligne le 01 juillet 2016, consulté le 26 septembre 2020. URL : http://

journals.openedition.org/abstractairanica/40312 ; DOI : https://doi.org/10.4000/abstractairanica. 40312

Ce document a été généré automatiquement le 26 septembre 2020.

Tous droits réservés 


\title{
Ibn-'Arabi, A. Penot. Les Révélations de la Mecque. [Anthologie traduite, commentée et annotée par A. Penot]
}

\author{
Ève Feuillebois-Piérunek
}

\section{RÉFÉRENCE}

Ibn-'Arabi, A. Penot. Les Révélations de la Mecque. [Anthologie traduite, commentée et annotée par A. Penot], Paris, Entrelacs, 2009, 457 p.

1 La synthèse définitive de l'enseignement d'Ibn 'Arabī (1165-1240) est contenue dans Les Révélations de La Mecque (Al-Futūhāt al-Makkiyya), ouvrage dont le maître andalou entreprit la rédaction lorsqu'il était en pèlerinage dans la ville sainte. Cet ouvrage est assurément une somme de connaissances spirituelles relatives à la sagesse soufie, unique tant par la complexité que par la profondeur de sa doctrine et la subtilité de sa langue. Cette nouvelle traduction en langue française, anthologie de la première section des Futūhāt, s'accompagne de deux substantiels essais introductifs de Jean Annestay (Introduction à la cosmogonie islamique et introduction à la hiérarchie et aux catégories initiatiques, p. 23-109), de notes explicatives, d'une courte biographie d'Ibn 'Arabī, d'une bibliographie, d'un index des noms propres et lexique des termes arabes. 


\section{AUTEURS}

\section{ÈVE FEUILLEBOIS-PIÉRUNEK}

Université Sorbonne Nouvelle- Paris 3, Mondes iranien et indien, Paris 